\title{
Sustainable farming with native rocks: the transition without revolution
}

\author{
WILLIAM S. FYFE ${ }^{1}$, OTHON H. LEONARDOS ${ }^{2}$ and SUZI H. THEODORO ${ }^{3}$ \\ ${ }^{1}$ University of Western Ontario, Dept. Earth Sciences, London, Ontario, Canada N6A 5B7 \\ ${ }^{2}$ Universidade de Brasília, Centro de Desenvolvimento Sustentável \\ SAS Quadra 05, Bloco H sala 200, 70070-914 Brasília, DF, Brasil \\ ${ }^{3}$ Universidade de Brasília, Centro de Estudos Avançados Multidisciplinares \\ Núcleo de Estudos Agrários, Campus Darcy Ribeiro, Edifício Multiuso I, Bloco B, \\ $1^{\circ}$ Andar sala B1-50, 70910-900 Brasília, DF, Brasil \\ Manuscript received on September 29, 2005; accepted for publication on March 13, 2006; \\ contributed by WILLIAM S. FYFE* AND OTHON H. LEONARDOS*
}

"Let the beauty we love be what we do!"

Hafiz

\begin{abstract}
The development process which humanity passed through favored a series of conquests, reflected in the better quality of life and longevity, however, it also provoked upsets and severe transformation in the environment and in the human food security. Such process is driving the ecosystems to be homogeneous, and, therefore, the nutrients' supply, via nourishment. To change this panorama, the present work discusses the gains of incorporating the stonemeal technique as a strategic alternative to give back the essential fertile characteristics to the soils. This technology has the function of facilitating the rejuvenation of the soils and increasing the availability of the necessary nutrients to the full development of the plants which is a basic input for the proliferation of life in all its dimensions.
\end{abstract}

Key words: stonemeal, remineralize, soil remediation, sustainable agriculture.

\section{INTRODUCTION}

In the many parts of the globe, how many people suffer of bad nutrition? According to data of many research institutes, at least $1 / 5$ of the world population starves. On the other hand, developed countries, like the United States and some European countries consume most of what is produced in the world and there is no world that could sustain that level of consumption for all unless we change the way we fertilize our soils. Another remarkable difference in the world that shows such inequalities among people

\footnotetext{
*Member Academia Brasileira de Ciências Correspondence to: William S. Fyfe

E-mail: pjfyfe@uwo.ca
}

is the longevity rates (Japan 81.5 years, Botswana 36.1 years, Ethiopia 43.3 years). Recently, a Canadian magazine The Globe and Mail (October 12, 2004) listed the world's great problems. The first listed was food, the shortage to over a billion people. The second was water and that 4 billion people face water quality and quantity problems. Additionally, the Nobel Peace Prize, Wangari Maathai, from Kenya, writes about the problems of nutrition and soil erosion and the need to plant more trees.

It has been known for some time that soil and food quality is a complex subject. It is also necessary to have a food surplus for security. In 1888, following the huge eruption of Krakatoa in the South 
Pacific, even Europe had a year without summer (food shortage in northern countries and no wine in France in that year). What would happen if we had such a vast eruption tomorrow? Could our food reserves last for a year? Today, with changing climate and wind directions, the need for food reserves and therefore, surplus is critical and global.

It is interesting to reflect on the history of agriculture as with Egypt and the importance of the Nile floods that added mud and nutrients to the alluvial soil. The soil nutrient system involves (at least half the periodic table) array of chemical elements, the need for organic matter, the need for a complex array of microorganisms and minerals, which hold water. From the study of volcanic areas we know how long it takes to form good soil as with Hawaii and we also know that some soil is best for food and some for forests.

In fact, we should make better use of rocks and rock related materials, from ground basaltic and andesitic rocks to phosphate rocks to processed rocks and rock wastes such as fly ash to remineralize our soils to prevent great disasters and have a better future for the coming generations.

We must plan for the needs of future generations and there is no generation that food and water needs are not a very high priority. In general, females know better than men survival strategies. In our work on soils and foods, we must work with schools at all levels to guarantee food for the generations to come. All people must be educated to understand our life support systems.

It is always necessary to monitor water chemistry in agricultural regions, soil water and river water. One needs only to look at the chemical differences of river waters (e.g. the Mississippi compared to the Amazon and Negro). Rivers in laterite regions are low in nutrients, which show the differences in agricultural productivity (Fyfe 1989). We also know that water can be polluted with chemicals from mine wastes. It is interesting to contemplate that water can be mineralized with appropriate rocks and pumped to the land using wind power (zero chemical pollution!).

\section{SOIL REMEDIATION}

An important strategy makes the use of wastes in soil remediation. In India we have shown that coal ash can be very effective. Coal comes from plants, organisms and contains many key trace elements. But one must be careful. Before wastes are added to soil we must know the total chemistry (Li to U). We have found coal ash to be rich in arsenic and at times even gold and uranium. The same is true for all carbon wastes. An important aspect of soil deterioration is dust production. In many parts of the world the quantity of dust is huge today, particularly due to forest burning to clear land for agriculture. Dust is dominated by fine particles, clay minerals, key components in the ability of soil to hold water. Dust erosion can be reduced by careful tree planting. But if you live near active volcanoes, particularly andesite volcanoes, their dust can be remarkable in increasing soil productivity. For example, in parts of the west of U.S.A. during recent eruptions, wheat production doubled after the dust was deposited. We should also use the river sediments in such regions for soil remediation.

Considering such possibilities, the sediments deposited in rivers or retained in dams, as well as wastes from mines and rocks or its weathered sub products can have the function of attenuating erosion problems and loss of fertile soil. These materials act as renewable and remineralizing agents of soils in agricultural regions.

One of the factors of greater importance in determining the dissolution rate of the added primary minerals and hence the fertilization impact of their nutrients in a soil is the grain size and its superficial reactions. The smaller the grain size, the greater the dissolution will be. Results by Theodoro 2005 have shown that a widespread grain size distribution of the mineral particles in a given rock fertilizer is fundamental to balance the span of time the rock will last in the soil with crop productivity.

In the conflicts among the many actors who search sustainable agricultural production while minimizing environmental impacts, market con- 
siderations associated with social justice have become fundamental ingredients in the establishment of new standards of production. Shiki 1995 and Leonardos et al. 2000 remind that humanity faces two conflicting paradigms: the first is based on the domination over Nature and the second, on living in harmony with the environment. It shouldn't be forgotten that before the sustainability of anything else what must be sustainable is the web of life that would sustain human life. The existence of future generations must be guaranteed at the present time.

\section{STONEMEAL: A STRATEGY OF REVERSION TO SUSTAINABILITY}

We begin with the assumption that the actual agriculture model of large-scale farming is unsustainable. Short-term economic gains are obtained at the expense of biodiversity loss, quality of life and even survival of the future generations and of the biosphere as a whole. Furthermore, strictly from the economic view, many are the indicators that show that the production costs of modern agriculture have become greater than their benefits. The widespread subsidies or the amnesty of the farmers' debts is a good example that this has been the case.

In food and bio-fuel exporting countries, like Brazil, the harvest records is helping to pay the national public debt, but it is transforming vast tropical regions into great green deserts, made up by huge soybean fields and most recently by sugar cane and other biofuel plantations. The consequence of this is that both the flora and fauna has been systematically devastated, leaving only small areas of gallery forests. Despite the existence of severe environment protective legislation, at the end of the $20^{\text {th }}$ Century, this production model had drastically reduced the Cerrado biome to a few percent of what had existed a few decades ago. With the near end of the Cerrado in the beginning of the millennium, agribusiness and new agriculture frontiers have been moving to the Amazon region. Forest clearing and burning first started in the headwaters of the Amazon tributaries in what has been called the Deforestation Arch. Due to new settlements and agribusiness pressure devastation is now widespread at astonishing rates (greater than 2.4 million hectares a year). Forest clearing and burning generally starts along new highways and infrastructure roads. The impact of this is leading to apocalyptical predictions concerning the fate of the Amazon biome (a discussion of this has been repeatedly published in SCIENCE issues since 2004) as both the Brazilian and international institutions seem powerless to curb or manage the deforestation process.

Considering such tragic scenarios, it is necessary that farmers who find themselves affected or aware of the impact caused by such irrational agricultural production system carried out by the market forces of the globalized establishment and supported by public policies and incentives, put into practice alternative life-sustained strategies. In Brazil two agriculture ministérios (state departments) deal with agriculture production: Ministério da Agricultura Pecuária e Abastecimento (MAPA) is responsible for large agriculture enterprises such as non-sustainable grain production (mostly exported) which is financed by the big banks, particularly Banco do Brasil while the Ministério de Desenvolvimento Agrário (MDA) is involved with local small-farm more sustainable production which supply most of the food for the internal market. It should be also noted the asymmetrical relationship between the so-called modern agriculture related to big agribusiness and ecological agricultural production. While the former is moved by huge technological research budgets and a force in the range of a billion dollars a day, trivial sums finance the later.

The big issue seems to be: which strategies are possible to reverse this trend? We believe that one obvious alternative practice that could be added to any strategy that promotes a healthy soil-water-lifeagriculture system is the use of rocks to remineralize nutrient-depleted soils. Such technique, called stonemeal will certainly help resist the present trend and restore the soil chemistry equilibrium disrupted by the chemicals introduced with the Green Revolution technologic packages. Crushed rocks or accu- 
mulated sediments in reservoirs have ample availability in many agricultural areas. The rocks or sediments with potential use should be compounded or enriched in macro and micronutrients that are indispensable to plant nutrition. The use of rock powder can favor the rejuvenation of the soils, bringing back the chemical diversity of the bioma that was transformed by the productive greed. The stonemeal technology is seen as a strategy that makes possible the reestablishment of the nutritional balance of the soil, which in the last resort, is what sustain and make feasible the diversity of life and agriculture. It may even prevent or delay tragic forecasts.

It is known that the natural fertility of the soils is directly connected to the availability and the release of chemical nutrient-elements from the available rocks to the soil. Other soil fertility determinants factors include $\mathrm{pH}$, grain-size, structure, porosity, permeability, life matter etc and the time span of weathering and soil-formation processes which separate, regroup and concentrate the chemical compounds that will be used in plant nutrition and ultimately will feed humankind (Melfi et al. 1999). Stonemeal is based on these natural processes. The practice, available to all agricultural sector, is especially interesting family farmers who want to conserve the land for their children and wish to redesign the productive system following agro-ecological principles and nature itself. Besides, there is the advantage in reducing the economic dependency on external commodities, making local development feasible, along with social justice and food security.

Although it could greatly reduce or eliminate the need of chemical fertilizers, results in terms of productivity or short term gains could decrease in function of a complex array of reasons, such as: local availability of source rocks; long distance transportation; the low nutrients contents of local rocks and among other things, the eternal wish for unnecessary goods. Other problems that should be considered in stonemeal project implementation refer to the lack of policies that give incentives to the use of rock fertilization, the absence of regulation or standardization of market procedure and the lack of agreement on a standard chemical analysis procedure to evaluate the complex fertility potential of a rock fertilizer candidate. Much scientific research is still needed so we fully understand the overall and the detailed biogeochemical complexity of multinutrient behavior in rock-soil-water-life-agriculture productive systems and its effectiveness in healthy food production.

Overcoming such limitations, advancements in stonemeal technology should gradually contribute to sustain soil health and fertility, guaranteeing food production in social and environmentally sustainable ways. It is important to point out that in stonemeal alternative ecological model of agriculture, crop plantations should be in consortium with the natural vegetation in a scale that would not disrupt the biota resilience. Stonemeal is complementary to other agro-ecological practices (compost and green manure use, permaculture practices etc) and should be used in association with them as to ascertain that food production and food security takes place in healthy environment.

Stonemeal practices, unlike the polluting use of chemical fertilizers, close to vulnerable ecosystems, such as marshes, springs, river margins, riparian forests, and murundu fields well as other ecologically fragile areas where the water table crops out would keep dissolved nutrient in healthy natural levels. Positive results from field trials using stonemeal have been worldwide reported (e.g. Leonardos et al. 1987, van Straaten 2002, Theodoro 2005, Fonseca et al. 2003). Results showed by Dissanayake and Chandrajith 1999, Smedley et al. 1996 and Smith et al. 1996 point out the dependency between the availability or excess of determined nutrients in the soil and human and animal health. These authors mention that the study of the chemistry of the soil, rocks and sediments can indicate the preventive measures against a series of diseases with marked geographic distribution. Smedley et al. 1996 and Smith et al. 1996, suggest that in tropical regions, where the soils have high concentration of $\mathrm{Al}_{2} \mathrm{O}$, 
$\mathrm{SiO}_{2}$ and $\mathrm{Fe}_{2} \mathrm{O}_{3}$, the large reoccurrence of pneumonia cases, during the drought period, is related to the high percentages of aluminum in air dust due to population densification and increment of agricultural areas.

It is worth mentioning that no matter how much a technological alternative is improved towards a more sustainable agriculture development, the effect produced by such techniques like the stonemeal will not promote by itself the much needed social and economical changes in the rural area (Leonardos and Theodoro 1999). As reminded by Altieri 1995, it is inconceivable to promote ecological changes in the agricultural sector without promoting comparable changes in other related areas of society.

\section{CONCLUSIONS}

Agriculture use of the stonemeal technique has a good potential to improve food production along with social justice and environmental health if integrated to political strategies committed to promoting regional sustainable development. Input from all sciences is needed and science must dialogue with senses so the wisdom to avoid the destruction of the web of life that sustain humankind should prevail over any academic, politician or neoclassic economist dominant rationality that dictates otherwise, be it in the name of technological progress, greed or the mythical economic growth.

We think that certain conclusions were obvious. First, soil and its bioproductivity are very complex and to attack soil food problems we need teams with diverse expertise (e.g. agrogeologists, soil scientists, geochemists, chemists, mineralogists, microbiologists, climatologists, cultivation technologists, sociologists and particularly ecological economists that takes into account social and environmental costs.

Even though earth sciences are of great help in understanding the planet's dynamics, such as the weathering processes that supply rock nutrients to the soils, it will be the partnership of this knowl- edge with responsible agricultural practices and the traditional knowledge that could reverse the hegemonic cultural-political-economical system that is now destroying the biosphere we all belong.

\section{RESUMO}

O processo de desenvolvimento pelo qual passou a humanidade favoreceu uma série de conquistas, refletidas na melhoria da qualidade de vida e na longevidade, mas, também, provocou transtornos e transformações severas no meio ambiente e na segurança alimentar dos homens. Tal processo tem levado a uma homogeneização dos ecossistemas e, portanto, da oferta de nutrientes, via alimentação. Para mudar este panorama, o presente trabalho discute a possibilidade de incorporação da técnica de Rochagem como uma alternativa estratégica para devolver as características de fertilidade essenciais aos solos. Esta tecnologia tem a função de facilitar o rejuvenescimento dos solos e aumentar a disponibilidade de nutrientes necessários ao pleno desenvolvimento das plantas que é o insumo básico para a proliferação da vida em todos as suas dimensões.

Palavras-chave: rochagem, remineralização, remediação do solo, agricultura sustentável.

\section{REFERENCES}

Altieri MA. 1995. Agroecology: the science of sustainable agriculture. Westview Press. IT publications. $2^{\text {nd }}$ ed., London.

DissanayaKe DB AND ChandRAJith R. 1999. Medical geochemistry of tropical environments. Elsevier, Earth-Science Reviews 47: 919-258.

FONSECA R, BARRIGA FJSA AND Fyfe WS. 2003. Dam reservoir sediments as fertilizers and artificial soils. Case studies from Portugal and Brazil, Proceedings, Water and soil environments, biological and geological perspectives, KAZUE TAZAKI (Ed), International Symposium of the Kanazawa University $21^{\text {st }}$ - Century COE Program, Kanazawa, Japan, p. 55-62.

FYFE WS. 1989. Soil and Global Change, Episodes, vol. 12.

LEONARdos OH AND TheOdoro SCH. 1999. Fertilizer tropical soils for sustaineble development. Proceedings. International workshop on science for sus- 
tainable development in Latin America and Caribe. Rio de Janeiro. Academia Brasileira de Ciências, p. 143-153.

Leonardos OH, Fyfe WS and Kronberg BI. 1987. The use of ground rocks in laterite systems: an improvement to the use of conventional soluble fertilizers. Chem Geol 60: 361-370.

LEONARdos OH, THEOdoro SCH AND ASSAD ML. 2000. Remineralization for sustainable agriculture: A tropical perspective from a Brasilian viewpoint. In: Nutrient Cycling in Agroecosystems - Formerly Fertilizer Research 56: 3-9.

Melfi AJ, Cerri CC, Fritsch E And Formoso MLL. 1999. Tropical Soils: Genesis, distribution and degradation of lateritic pedological systems. In: Formoso AND CERri, Academia Brasileira de Ciências (Workshop on Tropical Soils), p. 7-30.

SHIKI S. 1995. Sustentabilidade do sistema agroalimentar nos cerrados: em busca de uma abordagem includente. In: Agricultura sustentável. Jaquariúna. EMBRAPA 2: 17-30.
Smedley PL, Edmunds WM And Pelig BKB. 1996. Mobility of arsenic in groundwater in the Obuasi gold mining area of Ghana: some implications for human health. In: ApPlETon JD, FugE R AND MCCALL GJH (Eds). Environmental geochemistry and health, Geological Society Special Publications, UK 113: 91-104.

Smith B, Brewar N, Crawford MB, Galimaka D, Mushiri SM AND ReEder S. 1996. The environmental geochemistry of aluminium in tropical terrains and implications to health. In: APPLETON JD, Fuge R AND MCCALl GJH (Eds), environmental geochemistry and health, Geological Society Special Publications, UK 113: 141-153.

THEOdORO SCH. 2005. Rochas para plantas: o resgate de uma produção alimentar sadia. CD-ROM II SUFFIB. São Paulo, SP, Brasil.

VAN STRAATEN P. 2002. Rocks for crops: Agrominerals of Sub-Saharan Africa. ICRAF, 338 p. 